\title{
IN SEARCH OF LOST IDENTITY: THE TRIESTINE NARRATIVES OF LINO CARPINTERI AND MARIANO FARAGUNA
}

\section{DONATELLA FISCHER}

\begin{abstract}
Sommario
Lino Carpinteri e Mariano Faraguna sono due autori tradizionalmente lasciati ai margini degli studi critici sulla letteratura triestina. Tuttavia, la loro narrativa che trova la sua espressione più complessa nella raccolta intitolata Le Maldobrìe, offre un punto di vista alternativo sulla difficile questione dell'identità culturale di Trieste e del suo entroterra. Le storie narrate nelle Maldobrìe evocano la vecchia Trieste imperiale e mettono in evidenza attraverso personaggi ordinari il difficile eppure ineluttabile rapporto con la cultura austro-ungarica. II passato diventa uno specchio in cui, attraverso piccole vicende quotidiane, viene riesaminato un aspetto centrale ed insopprimibile dell'identità triestina.
\end{abstract}

Within the body of Italian literature there are complex areas where the definition of literary, cultural and historical identity is blurred and controversial. The literature of Trieste, a frontier city par excellence, represents one of these areas as the thorny issue of identity lies right at the heart of its literary production, its way of life and historical background. Many writers have portrayed the elusiveness of Triestine identity with its Italian, Germanic, and Slav roots which, in their turn, contain a significant Jewish component. The sense of disorientation which often transpires 
from so many of these works is inextricably linked to the awareness of a fragmented cultural and literary identity. Inevitably, the tormented characters of Italo Svevo, such as Zeno Cosini of La coscienza di Zeno (1923) and Emilio Brentani of Senilità (1898) immediately come to mind. Svevo's name of course, as is well known, encapsulates the fragmentation of his own cultural identity. Svevo changed his original name Aaron Hector Schmitz to an Italian name, thus denying not only his Germanic origins but also his Jewish ones (Camerino, 2002:129-144).

Alongside Svevo, Scipio Slataper voiced the dilemma of Triestine identity in his Il mio Carso (1912), where the narrator's concern with the nature of identity acquires philosophical overtones. In the opening of this diary-like book the narrator addresses the reader in an emblematic way:

Vorrei dirvi: Sono nato in Carso, in una casupola col tetto di paglia annerita dalle piove e dal fumo [...]

Vorrei dirvi: Sono nato in Croazia, nella grande foresta di roveri $[\ldots]$

Vorrei dirvi: Sono nato nella pianura morava e correvo come una lepre per i lunghi solchi [...] (Slataper, 1995: 3).

Slataper was in fact born in Trieste (his mother was Italian and his father was a Slav), and not on the Carso, but Slataper was intensely aware that identity was less dependent on the actual place of birth than on a sense of cultural and psychological belonging. Giani Stuparich, on the other hand, approached this issue differently and in his 1941 novel Ritorneranno, set during the Great War, he conveys his own allegiance to Italy, while at the same time depicting the co-existence of different nationalities and political loyalties within a Triestine family (Stuparich, 1991).

Summing up all these perceptions, in more recent times, Claudio Magris has defined the word 'identity' as something pluralistic:

Naturalmente ci sono tante identità, quindi la parola identità credo debba sempre essere detta al plurale. Nessuno di noi ha 
una identità: noi abbiamo molte identità: per esempio quella nazionale, che è certamente importante, ma non è certo l'unica e neanche la più importante, anche se storicamente, politicamente e socialmente è un terreno ricco, drammatico, terribile e qualche volta tragico, quindi esige interesse. (Magris and Zoderer, 2003:17) ${ }^{1}$

The problematical perception of identity which emerges in authors such as Svevo, Slataper, Stuparich, and others, derives from this sense of plurality which, sometimes, is felt as a form of conflict. In their works Triestine identity ultimately escapes definition, to the point where there is almost no identity, with the result that Trieste and its multi-ethnic hinterland, seem to acquire "the meaning of nowhere" as Jan Morris evocatively put it (Morris, 2001:187) ${ }^{2}$. What is less well understood is that outside the canon of Triestine literature, as represented by the well-known writers already mentioned, the issue of the cultural identity of Trieste and its region is felt with similar urgency. It is however expressed very differently. Yet, the perspective of identity is seldom invoked in approaches to this type of literature. The purpose of this article is to analyse the theme of identity in two non-canonical Triestine authors, Lino Carpinteri (Trieste, 1921-) and Mariano Faraguna (Trieste, 1924-2001).

The most likely reason for that exclusion from the canon is that the body of their work is written in an often impenetrable Triestine and istroveneto dialect, but it may also be due to the fact that they concentrate on a Triestine proletarian underworld which is culturally so specific that it

1 See also Magris' novels Danubio, Microcosmi, Un altro mare or Lontano da dove, which are profound explorations of issues of identity and cultural belonging. See also Enzo Bettiza, who undertakes a similar quest in his 1985 novel Il fantasma di Trieste, and Fulvio Tomizza who investigated the problem of belonging in many novels such as his Franziska, and in his 1995 Alle spalle di Trieste. On multi-culturalism and the concept of Heimat in the North-East of Italy, see Pasinato (1999).

2 Morris describes Trieste as 'an hallucinatory city, where fantasy easily brushes fact [...]'. 
could be seen as alien outside the confines of Venezia Giulia ${ }^{3}$. Nevertheless, by virtue of their colourful vernacular, which in itself is a powerful example of a multi-layered identity, and by virtue of the underground world they depict and therefore of the alternative perspective they offer on the delicate issue of identity, their exclusion from the canon represents a great gap. The writings of Carpinteri and Faraguna focus not on a sophisticated middle-class intelligentzia but on characters who are almost invisible to the glamorous high society of the Austro-Hungarian empire: ordinary soldiers, sailors, workers, market women, fishmongers, and people of all trades who work behind the glittering façades of the imperial palaces. It is a humanity which has a Bruegel-like quality in its comical eccentricity but whose daily existence is marked by a sharp sense of tragedy.

Carpinteri and Faraguna co-wrote all their writings, whether poetry, fiction or plays, which explains why their names are always associated. However, despite appearing 'as one', their personalities were different and complemented each other. Faraguna inherited and absorbed from his family a rich oral history which inspired the books called Maldobrie, cowritten with Carpinteri. The latter, on the other hand, was the one who brought order to the extraordinarily inventive nature of Faraguna. Carpinteri somehow represents the 'rational' side of the two Triestine writers. He is himself an example of a complex cultural identity. Born in Trieste and profoundly attached to the city and its multi-level culture, Carpinteri's father was a Sicilian while his mother was Jewish. The Maldobrie represent the bulk of their joint work and comprise several volumes written between 1966 and 1983. This article focuses on some examples taken from these collections, but a comprehensive study of 3 However, in 1994 a sketch called Porto sconto ("porto nascosto", 'hidden harbour') was adapted
for the theatre and performed in Rome, to great acclaim, under the direction of Francesco Macedonio. 
Carpinteri and Faraguna's work would be a useful addition to the field of Triestine literature ${ }^{4}$.

The 'maldobrie' are 'comical sketches' deeply influenced by the humorous journalistic articles Carpinteri and Faraguna wrote for the weekly magazine Caleidoscopio and subsequently for La Cittadella from 1945. Maldobrie is philologically an interesting word, containing in itself several strands of Triestine linguistic identity. It means 'birbonata' or 'ribalderia' ('roguery') and claims both Latin and Croatian roots. The stories narrated in the Maldobrie are written in a dialect which is an intersection of triestino, istro-veneto and dalmato, and would merit a philological study in its own right. It is in any case a language which is iconic of the cultural background of the Julian regions but, over and above all this, the tales look back at the mighty and controversial presence of the Austro-Hungarian Empire to which Trieste, Istria and Dalmatia belonged until 1918.

Yet, Carpinteri and Faraguna wrote stories that never attempt to romanticise the Austro-Hungarian past even when it is evoked nostalgically through the elusive filters of memory. The dangers of romanticisation have been underlined by Magris in his book Il mito asburgico nella letteratura austriaca contemporanea:

L'impero austroungarico scompariva nel 1918. Ma per gli intellettuali e $\mathrm{i}$ poeti di quella civiltà, che videro improvvisamente distrutta la loro società e con essa le basi della loro vita e della loro cultura, per gli scrittori austriaci che si trovarono sbalzati in un nuovo clima politico, alle cui esigenze la loro formazione non poteva essere adeguata, la vecchia Austria absburgica si presentava, e si presenta talvolta ancora, come un'epoca felice e armoniosa, come un'ordinata e favolosa Mitteleuropa in cui pareva che il

4 The first book of the Maldobrie was written in 1966 and was followed by five other sequels: Prima della prima guerra (1967), L'Austria era un paese ordinato (1969), Noi delle vecchie province (1971), Povero nostro Franz (1976) and Viva l'A. (1983). 
tempo non corresse cosí veloce e cosí ansioso di dimenticare le cose e i sentimenti dell'ieri. Nella loro memoria quella veniva cosí ad essere "l'età d'oro della sicurezza". (Magris, 1996:13) $)^{5}$

For the characters of Carpinteri and Faraguna the past is a moment of reckoning, as well as an opportunity for personal and critical reflection. The stories, however, emphasise the incontestable historical differences of Triestine culture in relation to Italian culture, and its dependence on the vast hinterland of the city. They present cultural difference not as something to be ashamed of but rather to cherish. As Tullio Kezich pointed out in his introduction to the 1997 edition of Le Maldobrie. Noi delle vecchie province,

Il retroterra diverso non è più un peccato originale, di cui bisogna vergognarsi cancellandone le tracce e magari cambiando cognome, ma la composizione essenziale di un drammatico e labile equilibrio fra opposte tradizioni. L'aver individuato questa realtà sociologica e politica è un merito, soprattutto se inquadrato nella tendenza di assecondare sempre meglio la funzione che Trieste compie per amore o per forza. (Carpinteri \& Faraguna, 1997:4)

The stories of the Maldobrie are set during the twilight of the AustroHungarian Empire when its monumental structure, after many centuries, was cracking at the seams. The time of the narration is after 1918, in a largely unspecified present, and the tales are narrated by an old fishmonger, Sior Bortolo, who has a stall at the Ponte Rosso market. This used to be one of the most proletarian and colourful areas of Trieste (today it is largely gentrified). Ponte Rosso in the stories becomes a miniature city and a self-enclosed world where Bortolo tells his stories to

See also Pellegrini (1987:76-77). 
one of his most faithful and devoted clients: Siora Nina. She, unlike Bortolo, does not remember the past or does so only sketchily, despite having lived through the same historical changes as the fishmonger. Their differing memories add an important element to the dialogue between the two characters, as Siora Nina comes to represent a world that is already forgetting its own origins and roots. In her old age she is not so much the mirror of the past as the reflection of what future generations would become if Bortolo, the indefatigable story-teller, did not try to prevent the past from slipping away from memory. In this sense, their conversations are a verbal and visual dramatization of the tug-of-war between the need to remember 'the old days' and the instinct to bury them. Such inherent theatricality transforms Bortolo's humble stall into a makeshift stage where the histrionic minstrel-fishmonger enacts a collective memory through which he paints in front of the eyes of Siora Nina a tapestry of epic, and sometimes surreal, events ${ }^{6}$.

Bortolo features in many of his own stories although never as a lead actor and, like all his characters, he has profound connections with the sea: his present work depends on it and his mythical and varied career during the years of the Austro-Hungarian Empire was spent entirely aboard an extraordinary number of ships, where he worked in different guises with some inseparable friends. In his stories the past is a mirror which reflects a reality often distorted by the partiality of memory, but which nonetheless has to be confronted head-on. A good example of a satirical portrayal of the past and of the irrepressible attachment to it is the sketch L'avanzamento, from Le Maldobrie. As in all these sketches, small things prompt Bortolo's narrations, and in this story he explains to Siora Nina the capital importance of gold buttons during the Austrian Empire.

6 The tales of the Maldobrie, being so inherently theatrical, lend themselves well to stage adaptations and did indeed inspire a number of plays amongst which the most famous are Due paia di calze di seta di Vienna (1992) and Delikatessen. Ovvero "Sette sedie di paglia di Vienna" (1993). Carpinteri and Faraguna's plays are regularly performed in Trieste at the theatre La contrada, one of the most prominent playhouses of the city. For a survey of this company and their development in Trieste, see Quazzolo (1997). 
The gold buttons on the blue uniform distinguished officers from the lower ranks, who could only have silver buttons. It is a mere detail, but it is transformed into an allegorical image which sums up the strict military hierarchy of the Austrian Navy and the social status attached to it. Bortolo as usual lampoons such rigidity, and condemns the social injustice that derived from it by explaining that in proverbially over-disciplined and class-centred Austria only women married to officers could wear a hat. The others wore a common scarf instead:

Però l'Austria iera un paese ordinato. Capel meteva le mogli del'uficialità e dei graduati. El militar, semplice, gnente capel. Dove una campagnola, una volta, se gavessi preteso de meter capel e scarpe? Zavate e fazoleto in testa. Adesso ara! Le vien zò del monte che le par Alida Valli! (Carpinteri \& Faraguna , 1997:156)

His caustic remarks show that this ostensibly simple man of the people is a well trained thinker who is never an apologist for the Empire; rather he is its embittered critic. Yet, there is another side, which emerges from his parable-like narrative. The loss of one world has given rise to another which to him is alien, and, despite his previous dislike of class privilege, he regrets that in the present day there is no longer any sense of propriety. The collapse of the old order has mixed up people and classes (now peasant women wear hats, which was previously only for the upperclasses), and Bortolo, this vox populi, seems to be against the new social order. But, we should ask, is he really against it? Has he suddenly turned into a conservative character championing the old status quo, or is he rather voicing the sense of confusion brought about by the collapse of an old world which, for all its faults, was known, recognisable and predictable? The new world that he contemplates is the new élite of

7 Alida Valli was a famous Italian cinema star of the forties. She was born in 1921 in Pola, Istria, now Pula in Croatia. She continued to act until the seventies. 
social-climbers of the present times, where everybody is wearing gold buttons on blue jackets just to show that they have a yacht docked in the Marina. As he explains:

Ah, xe montura de yacht-man. I se mete cussí per far saver in tera che I ga la barca in mar. Se no, in tera, come se capiria che i ga la barca? (Carpinteri \& Faraguna, 1997:154)

The Austria that Bortolo recollects and depicts for his audience is far from perfect, yet the tale cynically points out that the present is a distorted exaggeration of the past, equally flawed and ultimately much more undignified. Interestingly, Bortolo's narration implies that far from condemning the intimidating class-system of the empire, the present generation re-invents its own social identity simply by aping it and reproducing it in vulgar form. Within this context, the title L'avanzamento appears in all its ramifications: literally it signifies 'military advancement' while figuratively it means 'promotion' and thus refers to the idea of 'advancement' in terms of 'social-climbing' of the new post-Empire bourgeoisie. Paradoxically, the past repeats itself as farce but we are asked to consider which one of these two types of class-system is the more dangerous: the original in all its austere inflexibility, or the new one which, at least in some quarters, seems to be a re-enactment rather than a critical reassessment of the past. There is a sense of danger and of foreboding in the fishmonger's words.

Every fable in the Maldobrie is unique despite being framed by the same structural format. Irony and cynicism are always the main components and are normally juxtaposed with a pervading sense of tragedy and loss. It is this latter trait, though, which is more evident in the later volumes of Maldobrie. As time slipped away, and memories lapsed more and more, the later volumes of Bortolo's fables dig into the past in a much more traumatic way, and trauma comes to the fore as one of the 
fundamental characteristics of these narratives ${ }^{8}$. This is expressed vividly in a 'maldobrìa' from the 1967 collection Prima della prima guerra, entitled Commedia dell'arte. The title is ironical and contains many resonances. It conjures up first and foremost the idea of 'improvisation' and everything in the story is improvised. Bortolo tells of a performance of an opera by Giuseppe Giacosa, La partita a scacchi, to be staged on 18 August 1914 to celebrate the Emperor's birthday, as was customary at the time. The title of the opera itself is symbolic as it refers satirically to the last 'chess game' of the Monarchy that was soon to be so overwhelmingly checkmated. Emblematically, there is no pomp and circumstance in this celebration: the Monarchy is in its last days, and is transformed into a grotesque travesty of its glorious past. In such a climate, it is only natural that Bortolo and his usual friends should feature in the opera, and the symbolism becomes even sharper when Bortolo and his friends are depicted as haphazardly dressed and with long hair since they cannot afford proper wigs. They are a motley crowd and resemble a cluster of clowns ready to perform a circus number. However, the final circus number and the most tragic one, is the very one which pre-empts their performance as on 29 July 1914 Austria declared war on Serbia. As Bortolo explains, with great regret:

Iera tuto pronto siora Nina. La parte tuta a memoria, che el prete in cesa, costumi cusidi, i cavei mi li gavevo fin qua sule spale e a Marco Mitis, anzi, fin tropo i ghe iera cressudi, che el gaveva dovesto zimarseli. Tuto pronto, insoma. (Carpinteri \& Faraguna, 1995:47)

The outbreak of the war is depicted as a nuisance rather than a cataclysmic event, but a few lines later the dimension of the tragedy is apparent as Bortolo explains that he and his friends in a short time were

8 The theory of trauma has brought a new dimension to literary and historical studies. See Felman \& Laub (ed.) (1992), and Caruth (1996). 
all sent to the front in Galicia, where the long hair they had grown to simulate wigs in one show, was shaved so that they could act in an infinitely more tragic one:

[...] Milenovecentoquatordici; ventinove luglio 1914. Guera ala Serbia, mobilitazion general. Tempo tre giorni ierimo tutti in Galizia. Mi, Marco Mitis, el giovine Miagostòvich, Piero Bùnicich e el povero Favreto.

Tuti in Galizia, rasadi a zero. (Carpinteri \& Faraguna, 1995:47)

Bortolo's last, lapidary words deserve some consideration. The fatal date of 29 July 1914 is almost engraved in his speech. The repetition conveys something shocking and definitive as that date marked the end of an era that would never come back and the beginning of a war that would change the balance of power forever. Bortolo's final words are delivered in his usual mocking style, but they are haunting when they depict the image of the five travelling actors who, having missed their opportunity to act for the Emperor's birthday, are finally sent to perform for him on the Galician front. There, in the last show staged by the Empire, all the different races of its provinces merge for the final stand and in a common bloodshed, as the heterogeneous names of the five friends so powerfully indicate. In a perverse manner, the fragmented identity of the empire becomes as one in the carnage of the battle-fields. Ironically though, in becoming one through blood, identity is also annihilated by war ('shaved' is revealed to be a blunt euphemism for 'killed'). It is because of this cultural annihilation that Bortolo's stories always strive to reclaim some world before the war; not because it was necessarily better, but because names, places and people were still recognisable. Ultimately, the Empire has betrayed these characters who, reduced to stand-up comedians in a game of chess which can have only one outcome, are going to be sacrificed in the name of an absurd power. 
The collapse of the Monarchy is referred to in all stories as "el ribalton de l'Austria" (literally 'the overturning of Austria'): the term is comical but extraordinarily powerful and comes from the Italian 'ribaltare' which means 'rovesciare' ('to overturn'). As the term implies, after the end of the Habsburg Empire, the world as known in those provinces was turned upside-down, made unrecognisable, and rendered immensely confused. This sense of disorientation and desperate survival is expressed movingly in a remake of Joseph Roth's Hotel Savoy, the 'maldobrìa' called Hotel Savoia which appears in the 1976 volume Povero Nostro Franz. As in Roth's story, the Empire has collapsed and, significantly, this time the name of the Hotel is Italian (Hotel Savoia), which is the surname of the Italian monarchy. Once more, as in Roth's tale, the hotel is the meeting point of a hoard of disparate characters, but very different from those depicted by the Austrian novelist. The characters in Bortolo's story are not ghost-like figures who find in the mysterious Hotel Savoy their only anchor point in an unknown city of central Europe. The city at the centre of Bortolo's tale is fully recognisable: it is post-1918 Trieste, a mere vestige of the rich and buzzing city it once used to be. Its Hotel Savoia is the place where a new bourgeoisie, who have been able to profit from the change of regime, convene to witness the launch of the ship Vulcania (also an Italian name) in the port of Trieste. But alongside the wealthy drift the dispossessed who have lost everything after 1918. These pariahs mix with the rich and powerful hoping to be noticed and employed. The historical change is mirrored also in the fact that the maritime Insurance Agency involved in the launch is no longer the Lloyd Austriaco but the Lloyd Sabaudo (now belonging to the realm of the Savoia), and Bortolo's Dalmatian friend Tonin Polidrugo decides to join the crowds at the Hotel to get help with finding a job. As Bortolo explains to the usual Siora Nina, before the war Polidrugo was the owner of a Hungarian-Croatian insurance company on the island of Lussino, but with the fall of Austria he lost everything:

(Siora Nina) Tonin Polidrugo gaveva Agenzia Maritima? 
(Bortolo) - Anca, siora Nina. Ma pretamente suo padre la gaveva prima, a Lussin. Agenzia dela Ungaro-Croata. No ve iera una gran roba., perché la Ungaro-Croata ve iera calcolada Compagnia scarta. Questo i calcolava, ma istesso ghe vigniva le sue bele spetanze [...] "Xe stà un ben diseva sempre Tonin - che el padre me sia morto prima del ribalton." Perché, capì, dopo dela Prima Guera, co' ze cascada l'Austria, no iera più la Ungaro-Croata e lori ga perso. (Carpinteri \& Faraguna, 2001:47)

Polidrugo indeed succeeds in being noticed and, like many people at the time, quickly changes sides and is employed by the Lloyd Sabaudo. The story finishes here, but its implications are wider. Polidrugo, a mixture of Italian and Dalmatian roots, is the allegory of a cultural identity which has to be rebuilt, indeed re-invented. And everything is re-invented in Trieste after 1918, street names, companies' names, even people's names would be translated into Italian to give the city and its inhabitants a new sense of national identity ${ }^{9}$. Behind the character's ultimate success, however, there is also the portrayal of a man wrenched from his own past and obliged to join the thousands who were looking for work in the new Trieste.

Lussino, and many other areas of Croatia, lost their economic strength after 1918 and were left, literally, disconnected from the main land. Rather like the characters of the tale Commedia dell'Arte, Polidrugo has become nothing more than a clown who has to perform an improvised show in front of the new Italian élite to be noticed and employed. Despite his success, one has the feeling that his opportunism only highlights further the tragedy of Polidrugo's loss so that Bortolo's last epigrammatic words sum up with tragic irony the quick change of allegiances to which people were compelled if they wanted to survive:

9 Fascism exploited the issue of Triestine identity by imposing an 'italianità' based on the suppression of all non-Italian identities. 
Xe stà cussì, siora Nina, che Tonin Polidrugo ga avudo l'Agenzia del Lloyd Sabaudo. In Piazza Granda. E sula pergola el bateva blù Savoia col nodo Savoia. Come el Re, povero. (Carpinteri \& Faraguna, 2001:53)

The old identity, as Polidrugo shows in his re-invention of himself, had to be quickly suppressed as something shameful, and replaced by the new one epitomised by the Italian flag on the balcony of his office. The flag is a crucial visual sign which suggests a common national identity and proclaims in public Polidrugo's new allegiances.

Hotel Savoia still retains much of the comicality of previous sketches, but such light-heartedness disappears almost completely in the 'maldobrìa' La berretta (the 'military hat'), from the 1969 volume L'Austria era un paese ordinato. In place of comedy, this story is characterised by an overriding bleakness which stems from a renewed sense of cultural and historical disorientation. Once more, Carpinteri and Faraguna suggest the end of the Monarchy through the smallest details of everyday life by focusing on the life of an ordinary sailor, Sangulin, whose aspiration is to be promoted and to be able to wear the officer's hat rather than the ordinary sailor's hat. As with the coveted gold buttons in L'avanzamento, for the central character the officer's hat is a sign of status but, more than this, it is a sign of belonging and of purpose. The story is set in the far-away Dalmatian island of Ulbo, a backwater of the Empire, but the only place where Sangulin can see his ambitions fulfilled:

[...] Fina che un giorno, vedé come che xe qualche volta anche capita le combinazioni, lo ciama suo santolo Toni a casa sua de lui $[\ldots]$ e el ghe disi [...] "Senti Piero, qua te xe forsi un'occasion, perché xe passà telegrama de Pola che $\mathrm{i}$ meti un semaforo a Ulbo [...] per regolamento de Marina de Guera, el semaforista devi esser almeno soto-piloto [...]". (Carpinteri \& Faraguna, 1996:253) 
The job is humble but for Piero Sangulin, deputy pilot, this is indeed the opportunity to be promoted and wear finally the coveted officer's hat. However, like many other characters, Sangulin is unremittingly faced with defeat. In this outpost of the Empire, at the end of the war people do not even realise that Austria has collapsed, something that underlines the remoteness of the furthest provinces of the Monarchy and therefore its fragmentation. The news of the defeat of Austria is broken abruptly by a friend who simply says to Sangulin: "Paiazzo, càvite quella bereta, che xe passà telegrama che l'Austria ga calà le armi” (Carpinteri \& Faraguna, 1996:254).

It is not a coincidence that Sangulin's friend calls him "paiazzo" (in Italian 'pagliaccio'), thus reiterating that the associations with the circus character. That is exactly what Sangulin is reduced to as the defeat of Austria marks his personal demise as well as the end of all his personal, if modest, ambitions. Now his doom is complete as he remains in the forgotten island with no more status or purpose. Bortolo comments laconically:

E Piero Sangulin, povero, ga pozà la bareta sula carega e no ga dito gnente. Cussì, siora Nina, ve xe cascada l'Austria a Ulbo. (Carpinteri \& Faraguna, 1996:254)

The crash of 1918 is evoked not through extraordinary events and battles, but through the simplest of gestures. Like an actor backstage, Sangulin takes off his costume yet the uniform and the hat are also much more than mere stage costumes. They are the external symbols of the sailor's innermost aspirations and of the world where he wanted to belong, so absurdly fragile on the one hand and yet so central to his identity on the other. Without that uniform and that hat, the sailor becomes a disembodied figure, because the uniform was Sangulin. On the other hand, the discarded military clothes come to represent a powerful metaphor of the ephemeral nature of a military power which has lost all purpose, while those who stubbornly believed in it, like Sangulin, who 
does not have the quick inventiveness of Polidrugo, are left only with its empty props. In this sense he conjures up the image of Joseph Roth's character Gabriel Dan in Hotel Savoy, a former soldier in the Austrian army who some time after the First World War arrives in an unnamed eastern town at the gates of Europe. Adrift in a place he does not recognise, Dan describes himself with these words:

I am wearing a Russian blouse which someone gave me, breeches which I inherited from a dead comrade, and a pair of still wearable boots the origins of which I cannot myself remember.

After five years I stand again at the gates of Europe. (Roth, 1986:9)

It is a lapidary language which evokes an unforgettable image of fragmentation and loss of roots, and which Carpinteri and Faraguna imported in the sad figure of their much more modest character of Sangulin.

The perception of identity as traumatic, alongside the need to relive the trauma in order to recreate a sense of belonging, is re-iterated even more urgently in a later tale entitled Porto sconto ('Hidden Harbour'). Technically this does not belong to the Maldobrie although Bortolo is still the narrator and Siora Nina his faithful and stunned audience. This fable is, however, much longer and more melancholic than the previous tales. Once more, the story takes place on a far-away island on the eastern fringes of the ex-Empire where a Captain Coglievina, returning home after the defeat of Austria, organises life as if Austria-Hungary had not collapsed. He has witnessed the end and:

De questo, più che altro, el Capitan Coglievina ve ga subito capì che gnente più iera e gnente mai più sarìa stado come prima. (Carpinteri \& Faraguna, 1994:32) 
At night however, after the daily pretence is over, the Captain, like Roth's Dan, faces the gates of Europe, and stares for hours at the dark sea, now empty and lonely. As he stands there, he sees other characters as lonely as himself, and equally aware of their purposelessness. There is therefore the sense that others, too, keep up the daily pretence to stave off the void left by the end of the Empire:

E el Capitan Coglievina de sabo de sera se meteva sempre in pergòlo del Governo maritimo e el vedeva Visco che tornava in paese marinavia dopo de gaver impizzà la Lanterna e, sentà sula bita del molo, el vecio Barba Checo, quel col orecìn, quel che gaveva fato in antico Capo Horn a vela e che una volta che ciapava la zima ai vapori e che adesso el vapor non rivava più, el stava sentà là sula bita a fumar e a vardar el mar. (Carpinteri \& Faraguna, 1994:46)

People who were once active cannot but stare at the sea that used to be full of trade. By contrast, the vast expanse of sea is now transformed into an element that brings isolation and beyond which there is an unknown new world. The sea no longer unites people and countries, but lurks menacingly in front of those whose life once depended on it, as something terribly alien and frightening. Both La berretta and Porto sconto convey the idea that in fact the whole world for their characters has become profoundly alien as old identities are submerged and replaced by new ones, yet unknown. The underpinning presence of Roth returns as such figures share the disorientation of Roth's character Trotta in The Emperor's Tomb. The officer, whose loyalty to the empire did not prevent his criticism of its endemic faults, at the end of the book is adrift in a ghost-like Vienna which bears the scars of war. His instinct is to find a point of reference on which to lean and he rushes into the Kapuzinergruft 
to find some consolation in front of the emperor's tomb ${ }^{10}$. It is clearly only an act of self-delusion as the memory of another time is no more than a granite grave. Memory gives him no solace, and he leaves the crypt asking himself "So where could I go now, I, a Trotta?" (Roth, The Emperor's Tomb 1999:157). It is certainly the question that haunts the sailor Sangulin, and Captain Coglievina as he stares into the void.

Ultimately, there is no solution to the plight of Carpinteri and Faraguna's characters. Their down-to-earth wisdom and their ability to fend off any idealization of the "good old days" before the War, never prevail over their endemic sense of purposelessness. The bizarre fishmonger Bortolo, their projected voice in the present, can only reiterate such despair in his endless stories at the market stall. As a narrator he does not judge his characters, nor does he condone them. In the same way, Bortolo never slips into political polemics. Towards his characters there is instead a great sense of understated compassion as if they had been the victims of events which were all beyond their own comprehension. On behalf of his characters Bortolo uses memory, the most elusive means of all but somehow the only one available, to give voice to their disaffection and in doing so he evokes an important side of Triestine identity. It is an aspect which may be controversial, it may have been suppressed and it may represent the agenda of an imperial ideology, but as Gabriella Zani comments in her introduction to one of the books, the past "è uno specchio $[\ldots]$ in cui è bene guardarsi, ogni tanto $[\ldots]$ " (Carpinteri \& Faraguna, 1997:9).

All of Carpinteri and Faraguna's characters look at themselves in the mirror, even when it is slightly distorted. Perhaps more importantly, as Bortolo's narrations show, the sketches are less frequently a quest for identity, in the style of Svevo or Slataper for instance, as an attempt to rescue from oblivion a specific component of Triestine cultural and ethnic identity which is inscribed in its collective memory.

10 The crypt in Vienna where all the Habsburgs are buried. 
As one of the actresses who played in a recent stage-adaptation of the Maldobrie underlined, the portrayal of the fall of the Habsburg Empire is the "highest form of poetry" in Carpinteri and Faraguna's sketches:

[...] non si tratta solo dei momenti più divertenti, per esempio la caduta dell'Impero Austro-Ungarico è un momento di altissima poesia di Carpinteri e Faraguna, che magari non fa ridere ma certo fa pensare a come le cose finiscono in un batter d'occhio, anche le cose più importanti, le più grandi [...] Appoggiando semplicemente un cappello su una sedia $[\ldots]$. (Geisi, 2006)

Indeed, simple gestures in Carpinteri and Faraguna's stories assume a poetical and metaphysical quality, and have the power of summing up in one single stroke the tragic course of history.

The present brief article has used only a few examples from the rich collection of Carpinteri and Faraguna's narratives in order to point out how, outside the traditional literary canon, these two writers manage to approach the issue of cultural identity in an alternative literary style redolent of the medieval street minstrels. Their work deserves to be explored further. The fact that, to date, Carpinteri and Faraguna do not feature in mainstream studies of Triestine literature is a loss to criticism as their work contributes a fresh perspective to the debate on Triestine identity. Bortolo's narrations are populated by voices which come from the bowels of Trieste, from the invisible world of its backstreets and its seedy harbour quays, where jacks-of-all-trades roam looking for work and alcohol. Yet, they are a mournful chorus which speaks of loss and disorientation, and begs to be listened to.

(University of Glasgow, UK) 


\section{Bibliography}

\begin{tabular}{|c|c|c|}
\hline Camerino,G.A. & 2002 & $\begin{array}{l}\text { Svevo e la crisi della Mitteleuropa. Napoli: } \\
\text { Liguori. }\end{array}$ \\
\hline $\begin{array}{l}\text { Carpinteri, L. \& } \\
\text { Faraguna, M. }\end{array}$ & 1992 & $\begin{array}{l}\text { Due paia di calze di seta di Vienna. Trieste: } \\
\text { MGS. }\end{array}$ \\
\hline $\begin{array}{l}\text { Carpinteri, L. \& } \\
\text { Faraguna, M. }\end{array}$ & 1993 & $\begin{array}{l}\text { Delikatessen. Ovvero "Sette sedie di paglia di } \\
\text { Vienna". Trieste: MGS. }\end{array}$ \\
\hline $\begin{array}{l}\text { Carpinteri, L. \& } \\
\text { Faraguna, M. }\end{array}$ & 1994 & Porto Sconto. Tireste: MGS. \\
\hline $\begin{array}{l}\text { Carpinteri, L. \& } \\
\text { Faraguna, M. }\end{array}$ & 1995 & Prima della prima guerra.Trieste: MGS. \\
\hline $\begin{array}{l}\text { Carpinteri, L. \& } \\
\text { Faraguna, M. }\end{array}$ & 1996 & L'Austria era un paese ordinato. Trieste: MGS. \\
\hline $\begin{array}{l}\text { Carpinteri, L. \& } \\
\text { Faraguna, M. }\end{array}$ & 1997 & $\begin{array}{l}\text { Le Maldobrie. Noi delle vecchie province. } \\
\text { Trieste: MGS. }\end{array}$ \\
\hline $\begin{array}{l}\text { Carpinteri, L. \& } \\
\text { Faraguna, M. }\end{array}$ & 1997 & Cosa dirà la Débegnac. Trieste: MGS. \\
\hline $\begin{array}{l}\text { Carpinteri, L. \& } \\
\text { Faraguna, M. }\end{array}$ & 1999 & Le Maldobrie. Trieste: MGS. \\
\hline $\begin{array}{l}\text { Carpinteri, L. \& } \\
\text { Faraguna, M. }\end{array}$ & 2001 & Povero nostro Franz. Trieste:MGS. \\
\hline Caruth, C. & 1996 & $\begin{array}{l}\text { Unacclaimed Experience. Trauma, Narrative } \\
\text { and History. Baltimore: John Hopkins } \\
\text { University Press. }\end{array}$ \\
\hline
\end{tabular}


Felman, S. \& Laub, D. 1992 Testimony: Crises of Witnessing in Literature, (ed.) Psychoanalysis and History. London: Routledge.

Gelsi, G.

2004 Contrada: Omaggio a Trieste. Fucine Mute, http://www.fucine.com/archivio/fm64/gelsi.htm (Accessed in June 2008).

Magris, C.

1996 Il mito asburgico nella letteratura austriaca contemporanea, Torino: Einaudi.

Magris, C. \&

2003 Identità e multiculturalità. Bolzano: Edizioni Zoderer J. Junior.

Morris, J.

2001 Trieste and the Meaning of Nowhere. London: Faber \& Faber.

Pasinato, A. (ed.)

1999 Heimat. Identità regionali nel processo storico. Roma: Donzelli.

Pellegrini, E.

1997 La Trieste di carta. Aspetti della letteratura triestina del novecento. Bergamo: Pierluigi Lubrina Editori.

Quazzolo, P.

1997 Vent'anni di Contrada. Trieste: Lint.

Roth, J.

1986 Hotel Savoy. London: Granta.

Roth, J.

1999 The Emperor's Tomb. London: Granta.

Slataper, S.

1995 Il mio carso. Milano: Mondadori.

Stuparich, G.

1991 Ritorneranno. Milano: Garzanti. 